WAHANA

AKUNTANSI

Jumal Ilmial
JURNAL ILMIAH WAHANA AKUNTANSI

Vol 13 (1) 2018, 13-28

http://journal.unj.ac.id/unj/index.php/wahana-akuntansi

\title{
AKUNTABILITAS DAN TRANSPARANSI PELAPORAN KEUANGAN PEMERINTAH DAERAH SERTA POTENSI WHISTLEBLOWING ATAS PENYALAHGUNAAN DANA
}

\author{
Anggi Saputra* \\ Intiyas Utami \\ Ika Kristianti \\ Universitas Kristen Satya Wacana
}

Keywords:

Accountability, Civil Servant,

Good governance,

Transparency, Whistleblowing

\begin{abstract}
The high level of corruption in the Indonesian government sector makes good governance difficult to achieve. Accountability and transparency is a must in the effort to realize good governance. The efforts to reduce the level of corruption in Indonesia is the awareness of civil servants to disclose the fraud in the workplace agencies. This research uses qualitative methods with the aim to describe the implementation of accountability and transparency of local government financial reporting as well as identify potential whistleblowing for misuse of funds. This research uses primary data in the form of in-depth interviews with informants and secondary data in the form of financial statements of Salatiga local government that has been audited by BPK. The resource persons in this research are civil servants domiciled in Salatiga City and work in SKPD Salatiga City in the finance department of each SKPD. The results of this research indicate that Salatiga City Government has been accountable and transparent in local government financial reporting as well as there is no potential whistleblowing for misuse of funds. The results of this research can be used as an evaluation material for government agencies to establish a good whistleblowing mechanism so that civil servants working in government agencies are more willing to disclose the fraud.
\end{abstract}

\begin{abstract}
Abstrak
Tingginya tingkat korupsi di sektor pemerintah Indonesia membuat pemerintahan yang baik sulit untuk dicapai. Akuntabilitas dan transparansi adalah suatu keharusan dalam upaya mewujudkan pemerintahan yang baik. Upaya untuk mengurangi tingkat korupsi di Indonesia adalah kesadaran pegawai negeri untuk mengungkapkan penipuan di agen tempat kerja. Penelitian ini menggunakan metode kualitatif dengan tujuan untuk menggambarkan pelaksanaan akuntabilitas dan transparansi pelaporan keuangan pemerintah daerah serta mengidentifikasi potensi whistleblowing untuk penyalahgunaan dana. Penelitian ini menggunakan data primer berupa wawancara mendalam dengan informan dan data sekunder berupa laporan keuangan pemerintah daerah Salatiga yang telah diaudit oleh BPK. Narasumber dalam penelitian ini adalah pegawai negeri yang berdomisili di Kota Salatiga dan bekerja di SKPD Kota Salatiga di bagian keuangan masing-masing SKPD. Hasil penelitian ini menunjukkan bahwa Pemerintah Kota Salatiga telah akuntabel dan transparan dalam pelaporan keuangan pemerintah daerah serta tidak ada potensi whistleblowing untuk penyalahgunaan dana. Hasil penelitian ini dapat digunakan sebagai bahan evaluasi bagi instansi pemerintah untuk membentuk mekanisme whistleblowing yang baik sehingga pegawai negeri yang bekerja di instansi pemerintah lebih bersedia untuk mengungkapkan kecurangan.
\end{abstract}

How to Cite:

Saputra, Anggi, Intiyas Utami, dan Ika Kristianti. (2018). Akuntabilitas dan Transparansi Pelaporan Keuangan

Pemerintah Daerah Serta Potensi Whistleblowing atas

Penyalahgunaan Dana. Jurnal Ilmiah Wahana Akuntansi, 13(1), 13-28 https://doi.org/https://doi.org/10.21009/ wahana.013.1.2 


\section{PENDAHULUAN}

Banyak tantangan yang harus dihadapi pemerintah untuk mewujudkan good government governance mengingat pelayanan pemerintah untuk publik telah tercemar oleh berbagai tindakan kecurangan (fraud) yang kemudian mengarah pada prakktek korupsi, kolusi dan nepotisme (KKN). Tipologi fraud yang paling menjadi perhatian dan sensitif di sektor publik di Indonesia adalah korupsi. Berdasarkan data Corruption Perceptions Index (CPI) yang diterbitkan Transparency International (TI), pada tahun 2016 In donesia menempati peringkat 90 dengan nilai 37 dari keseluruhan 176 negara yang diukur (TI, 2017). Hal ini menunjukkan bahwa sampai saat ini tingkat korupsi di Indonesia masih tergolong tinggi.

Output dari tugas pokok dan fungsi lembaga atau instansi pemerintah adalah pelayanan yang diberikan kepada masyarakat. Akuntabilitas dan transparasi merupakan suatu keharusan dalam proses pelayanan (KPK, 2014). Fakta layanan publik di Indonesia menunjukan bahwa korupsi dalam bentuk gratifikasi, pemerasan, penyuapan ataupun penyalahgunaan wewenang masih sangat rawan pada sektor ini.

Berdasarkan hasil pemeriksaan BPK, Laporan Keuangan Pemerintah Daerah (LKPD) Kota Salatiga tahun 2016 y ang merupakan objek penelitian mendapatk an predikat Wajar Tanpa Pengecualian (WTP). Hal tersebut merupakan pencapaian terbaik yang didapat Pemerintah Kota dikarenakann dari tahun 20062015 LKPD Kota Salatiga hanya mendapat opini Wajar Dengan Pengecualian (WDP) (PemkotSalatiga, 2017). Hal ini tentunya tidak sejalan dengan kenyataan bahwa masih banyak kasus korupsi yang terjadi di Salatiga. Dalam upaya memberantas korupsi masyarakat harus ikut berpartisipasi aktif dan tidak bisa sebatas mengandalkan lembaga-lembaga pemberantas korupsi, terutama korupsi di sektor pemerintahan. Salah satu upaya yang bisa dilakukan masyarakat untuk memberantas korupsi adalah dengan menjadi whistleblower dilingkungan sosial maupun tempat bekerja.

Whistleblowing system yang baik dan efektif dapat diwujudkan apabila seluruh elemen yang terlibat maupun masyarakat ikut berpartisipasi didalamnya. Di Indonesia sendiri sudah banyak kasus-kasus yang berhasil diungkap berkat adanya peran whistleblower. Kasus-kasus tersebut diantaranya adalah kasus suap yang Walikota Semarang Soemarmo kepada anggota DPRD tahun 2012 dengan whistleblower Akmad Zaenuri yang, kasus penggelapan, kasus penyuapan dalam pemilihan Deputi Gubernur Senior Bank Indonesia pada tahun 2004 yang diungkapkan oleh Agus Condro, kasus korupsi proyek Hambalang yang diungkapkan oleh Muhammad Nazaruddin.

Objek penelitian ini dilakukan di Kota Salatiga karena dalam beberapa tahun terakhir banyak kasus korupsi di Salatiga yang tentu saja merugikan negara dan masyarakat namun juga laporan keuangan pemerintah kota mendapatkan opini wajar tanpa pengecualian pada tahun 2016. Kasus tersebut antara lain kasus korupsi pengadaan buku ajar oleh mantan sekretaris daerah Kota Salatiga tahun 2003- 
2004, kasus korupsi proyek GOR Kridanggo pada tahun 2011, kasus korupsi jalan lingkar Salatiga pada tahun 2008 yang melibatkan Wali Kota Salatiga pada waktu itu serta kasus korupsi pengelolaan dana Perusahaan Daerah Aneka Usaha (PDAU) Salatiga antara tahun 2006-2008 yang juga melibatkan pejabat terkait..

Penelitian ini bertujuan untuk mendeskripsikan pelaksanaan akuntabilitas dan transparansi pelaporan keuangan pemerintah daerah serta mengidentifikasi potensi whistleblowing atas penyalahgunaan dana.

\section{KAJIAN PUSTAKA, KERANGKA PEMIKIRAN, DAN HIPOTESIS \\ Whistleblowing}

Keraf (2008) menyatakan bahwa whistleblowing merupakan suatu tindakan membocorkan kecurangan atasan maupun perusahaan kepada pihak lain yang dilakukan oleh satu maupun beberapa karyawan dalam perusahaan tersebut. Orang yang melaporkan maupun mengungkapkan kecurangan disebut dengan whistleblower. Hal penting untuk menjadi whistleblower adalah adanya bukti, indikasi dan informasi yang jelas atas pelanggaran yang akan dilaporkan sehingga kemudian dapat ditindaklanjuti oleh pihak yang berwenang.

\section{Menurut Mesmer-Magnus dan} Viswesvaran (2005) dalam instansi pemerintah, pengguna potensial diterapkannya sistem whistleblowing adalah para pegawai negeri sipil yang bertindak sebagai karyawan. Hal ini dikarenakan mereka terlibat langsung secara teknis maupun dalam kegiatan operasional pemerintah. Pegawai negeri sipil memilki informasi rinci tentang proses berjalannya kegiatan operasional dan bagaimana instansi pemerintah tersebut bekerja, sehingga merekalah yang paling mungkin mengetahui tindakan-tindakan yang berkaitan dengan keberadaan korupsi di lingkungan tempat kerjanya.

Seorang whistleblower harus memiliki keberanian dan keyakinan karena tindakan ini memang penuh risiko. Banyak sekali risiko yang harus dihadapi seorang whistleblower berkaitan dengan kehidupan pribadi dan

pekerjaanya. Tidak jarang seorang whistleblower mendapat ancaman-ancaman dan teror pembunuhan dari orang-orang yang merasa dirugikan dan tidak menyukai keberadaannya. Park dan Blekinsopp (2009) men gungkapkan bahwa resiko pembalasan yang mungkin diterima oleh pelaku whistleblower seccara tidak langsung dapat mempengaruhi niat individu untuk mengungkapkan kecurangan yang ada.

Sebagai bentuk perlindungan terhadap para pelaku whistleblower, Pemerintah Indonesia telah menerbitkan Undang-Undang Nomor 13 Tahun 2006 tentang Perlindungan Saksi dan Korban. Undang-undang ini berisi tentang hak saksi untuk memperoleh perlindungan atas keluarga, keamanan pribadi dan harta bendanya, serta bebas dari ancaman yang terkait dengan kesaksian yang akan, sedang, atau telah diberikan. Saksi juga diberikan hak untuk mendapatkan bantuan biaya hidup sementara hingga batas waktu perlindungan berakhir. Perlindungan ini diberikan oleh 


\section{Akuntabilitas}

Menurut Peraturan Pemerintah Nomor 71 Tahun 2010 tentang standar akuntansi pemerintah, akuntabilitas merupakan bentuk

pertanggungjawaban atas pengelolaan pelaksanaan kebijakan serta sumber daya yang di telah dipercayakan kepada entitas pelaporan dalam mencapai tujuan yang sudah ditetapkan secara periodik. Akuntabilitas menjadi salah satu komponen pokok guna mewujudkan good governance.

Ciri-ciri pemerintah yang accountable menurut Sopanah (200 5):

1. Menyajikan informasi dalam penyelenggaraan pemerintah secara cepat, tepat dan terbuka kepada masyarakat.

2. Memberikan pelayanan yang baik dan memuaskan kepada masyarakat.

3. Memberikan ruang kepada publik untuk bisa terlibat dalam pembangunan dan pemerintahan.

4. Mampu mempertanggungjawabkan dan menjelaskan secara proporsional setiap kebijakan kepada masyarakat.

5. Terdapat sarana publik guna menilai pencapaian kegiatan pemerintah dan pelaksanaan progam.

Mardiasmo (2002) menjelaskan ada dua macam akuntabilitas publik, yaitu akuntabilitas vertikal dan akuuntabilitas horisontal. Akuntabilitas vertikal merupakan bentuk pertanggungjawaban atas pengelolaan sumber dana kepada otoritas yang mempunyai wewenang lebih tinggi, misalnya: pertanggungjawaban Pemda terhadap pemerintah pusat dan pertanggungjawaban pemerintah pusat kepada MPR. Sedangkan akuntabilitas horisontal merupakan bentuk pertanggungjawaban kepada masyarakat baik melalui lembaga perwakilan rakyat maupun secara langsung.

\section{Transparasi}

Transparansi merupakan keterbukaan atas segala kebijakan dan tindakan yang dilakukan oleh suatu entitas maupun instansi. Peraturan Pemerintah Nomor 71 Tahun 2010 tentang standar akuntansi pemerintah menjelaskan bahwa transparansi berarti memberikan informasi keuangan yang jujur dan terbuka kepada masyarakat luas. Hal tersebut

didasarkan atas pertimbangan bahwa masyarakat mempunyai hak untuk mengetahui secara menyeluruh dan terbuka atas

pertanggungjawaban pemerintah dalam mengelola kebijakan dan sumber daya yang telah dipercayakan kepadanya serta ketaatannya atas perundang-undangan yang berlaku.

$$
\text { Erlanda dan Khairudin }
$$

menyatakan asas keterbukaan merupakan salah satu unsur guna mewujudkan penyelenggaraan negara yang bersih dan bebas dari KKN. Asas keterbukaan yang dimaksud disini adalah asas untuk membuka diri berkaitan dengan hak masyarakat untuk memperoleh informasi yang jujur, benar serta tidak diskriminatif tentang proses penyelenggaraan negara yang tetap memperhatikan perlindungan atas rahasia negara, golongan dan hak asasi pribadi.

Andrianto (2007) mengungkapkan beberapa manfaat penting adanya transparansi anggaran dalam pemerintahan, yaitu mencegah 
korupsi, meningkatkan akuntabilitas pada pemerintahan sehingga masyarakat lebih mampu untuk mengukur kinerja pemerintah, lebih mudah dalam mengidentifikasi kekuatan dan kelemahan kebijakan, dapat meningkatkan kepercayaan untuk merumuskan kebijakan

terhadap komitmen pemerintah, dapat membentuk kepercayaan publik, mening katkan kepastian dalam usaha dan iklim investasi yang lebih baik.

Transparansi bertujuaan untuk membangun keyakinan dan kepercayaan kepada pemerintah daerah bahwa pemerintah daerah merupakan instansi pelayanan publik yang profesional dan bersih dari tindakan korupsi, kolusi dan nepotisme (Kusuma, 2012). Logos (2003) dalam Kusuma (2012) mengatakan bahwa akuntabilitas dan transparansi adalah komponen yang saling berkaitan satu sama lain, karena transparansi tidak akan bermanfaat tanpa dilengkapi akuntabilitas. Sebaliknya tanpa transparansi akuntabilitas tidak akan ada.

\section{Pelaporan Keuangan Pemerintah Daerah}

Salah satu komponen penting guna menciptakan akuntabilitas sektor publik adalah dengan adanya laporan keuangan organisasi sektor publik. Pemerintah daerah harus menyampaikan pertanggungjawaban dengan membuat laporan keuangan yang terdiri dari neraca, laporan realisasi angggaran, laporan arus kas dan catatan atas laporan keuangan dan kemudian dilampiri dengan laporan keuangan perusahaan daerah yang disusun sesuai SAP.

Kewajiban pemerintah menyampaikan pertanggungjawaban tersebut berdasarkan pada
Undang-Undang Nomor 17 Tahun 2003 tentang keuangan negara (Mardiasmo, 2002).

Tingkat pengukuran kinerja keuangan pemerintah daerah diukur berdasarkan hasil audit BPK RI atas laporan keuangan pemerintah daerah setiap tahunnya. Terdapat tiga kriteria penilaian atas hasil audit pada LKPD yang telah diaudit, yaitu hasil opini audit atas laporan keuangan, kelemahan SPI dan ketaatan atas perundang-undangan yang berlaku (Heriningsih dan Marita, 2013).

Opini auditor merupakan hal penting dalam setiap laporan kinerja suatu entitas karena menunjukkan kualitas kinerja pada entitas yang bersangkutan. Berdasarkan hal tersebut jika pemerintah daerah mendapatkan opini WTP (wajar tanpa pengecualian) maka seharusnya kinerja pemerintah daerah yang bersangkutan dapat dikatakan baik dan korupsi tidak dapat terjadi. Sedangkan apabila ditemukan kelemahan pada SPI yang dijalankan maka akan menjadi tambahan masukan untuk periode berikutnya agar lebih berjalan baik dan efektif. Ketaatan atas perundang-undangan yang berlaku dapat dijadikan da sar bahwa

apabila semakin banyak ditemukan ketidaktaatan terhadap perundang-undangan maka kemungkinan terjadinya korupsi juga semakin besar (Heriningsih dan Marita, 2013).

\section{OBJEK \& METODE PENELITIAN Desain Penelitian}

Penelitian ini menggunakan metode kualitatif dengan tujuan mendeskripsikan pelaksanaan akuntabilitas dan transparansi pelaporan keuangan pemerintah daerah serta 
mengidentifikasi potensi whistleblowing atas penyalahgunaan dana. Objek penelitian dilakukan di Kota Salatiga, Jawa Tengah. Data pada penelitian ini menggunakan data primer dari hasil wawancara mendalam kepada para narasumber dan data sekunder berupa laporan keuangan pemerintah daerah Kota Salatiga yang telah diaudit oleh BPK.

Pemilihan narasumber dilakukan menggunakan purposive sampling dengan kriteria narasumber yang berdomisili di Kota Salatiga dan bekerja di satuan kerja pemerintah daerah (SKPD) pada bagian keuangaan masingmasing SKPD. SKPD yang akan digunakan sebagai tempat penelitian yaitu: 1. Dinas Perdagangan; 2. Dinas Lingkungan Hidup; 3. Dinas Pekerjaan Umum dan Penataan Ruang; 4. Dinas Pendidikan; dan 5. Dinas Perumahan dan Kawasan Pemukiman. Aspek penting yang dijadikan fokus penelitian ini adalah akuntabilitas dan transparansi pelaporan keuangan pemerintah daerah serta pote nsi whistleblowing pegawai negeri sipil atas penyalahgunaan dana.

Analisis kualitatif pada penelitian ini dilakukan secara bertahap yaitu:

1. Menyajikan gambaran umum objek penelitian.

2. Melakukan wawancara secara mendalam kepada para narasumber.

3. Membaca data secara keseluruhan.

4. Menganalisis secara detail dengan mengolah informasi kedalam segmen tulisan atau laporan kualitatif.

5. Menyimpulkan hasil informasi yang sudah dianalisis dan diolah sesuai dengan tujuan penelitian.

\section{PEMBAHASAN}

\section{Gambaran Umum Kota Sal atiga}

Salatiga merupakan kota kecil yang terletak di provinsi Jawa Tengah. Kota ini memiliki luas wilayah $\pm 56,78 \mathrm{~km}^{2}$ dan mempunyai 22 kelurahan serta 4 kecamatan dengan total penduduk 176.795 jiwa . Kota Salatiga terletak pada jalur regional Jawa Tengah yang menghubungkan Kota Surakarta dan Kota Semarang. Terletak pada ketinggian 450-800 meter dari permukaan laut, Kota Salatiga memiliki hawa sejuk dan beriklim tropis dengan dikelilingi beberapa gunung seperti gunung Merbabu, gunung Telomoyo dan gunung Gajah Mungkur (PemkotSalatiga, 20 17).

\section{PEMBAHASAN}

\section{Gambaran Umum Kota Sal atiga}

Salatiga merupakan kota kecil yang terletak di provinsi Jawa Tengah. Kota ini memiliki luas wilayah $\pm 56,78 \mathrm{~km}^{2}$ dan mempunyai 22 kelurahan serta 4 kecamatan dengan total penduduk 176.795 jiwa. Kota Salatiga terletak pada jalur regional Jawa Tengah yang menghubungkan Kota Surakarta dan Kota Semarang. Terletak pada ketinggian 450-800 meter dari permukaan laut, Kota Salatiga memiliki hawa sejuk dan beriklim tropis dengan dikelilingi beberapa gunung seperti gunung Merbabu, gunung Telomoyo dan gunung Gajah Mungkur (PemkotSalatiga, 20 17).

\section{Pelaksanaan Akuntabilitas Laporan Keuangan SKPD}


Dalam rangka pertanggungjawaban keuangannya pihak dinas menghasilkan beberapa laporan keuangan seperti Laporan

Realisasi Anggaran (LRA), Laporan Operasional (LO), Neraca, Laporan Perubahan Ekuitas (LPE) dan Catatan Atas Laporan Keungan (CALK). Laporan-laporan tersebut nantinya diserahkan kepada Badan Keuangan Daerah (BKD) guna dilakukan rekonsiliasi sebelum nantinya dikonsolidasi oleh Pemerintah Kota Salatiga, seperti yang dikemukakan oleh Ibu A dari Dinas Perdagangan:

"Kalau informasi yang dihasilkan untuk pertanggungjawaban keuangan perangkat daerah itu kita terdiri dari LRA, LPE, LO, Neraca dan Catatan atas Laporan Keuangan, itu harus ada semua mas, itu yang menyusun laporan keuangannya ada PPK, bendahara pengeluaran dan penerimaan sama ada adminnya yang bertugas menginput dan menjurnal data-data yang digunakan untuk penyusunan $L K$ dan nanti ditujukan untuk Walikota melalui BKD namun sebelumnya dilakukan rekonsiliasi dulu."

Sedangkan Ibu B dari Dinas Pendidikan mengemukakan:

"Untuk pertanggungjawaban keuangannya ada LRA, LO, Neraca, LPE sama CALK mas, yang menyusun pejabat penatausahaan keuangan trus dilaporkan untuk entitas pelapor yaitu BKD guna dilakukan rekonsiliasi untuk kemudian nanti dikonsolidasi oleh pemkotnya."

Hal senada juga diungkapkan oleh Ibu C dari Dinas Lingkungan hidup yang mengungkapkan:

"Itu kita ada LRA, Neraca, LO, LPE, sama
CALK untuk laporan pertanggungjawaban keuangannya, nah kalau yang menyusun itu ada subbagian perencanaan dan keuangan. Nantinya laporan keuangan tersebut ditujukan untuk BKD mas sebelum nanti sampe ke pemkot."

Pernyataan yang sama diungkapkan pula oleh Ibu D dari Dinas Perumahan dan Kawasan Pemukiman, beliau mengungkapkan:

"Jadi kita pertanggungjawabanya terdiri dari LRA, LO, LPE, Neraca sama CAlk, kalo yang nyusun itu oleh pejabat penatausahaan keuangan dan ditujukan buat BKD, pemerintah kota sama pihak-pihak yang berkepentingan."

Hal ini semakin diperkuat oleh pernyataan yang diungkapkan Bapak E dari Dinas Pekerjaan Umum dan Penataan Ruang:

"Untuk laporan pertanggungjawabannya itu ya macem-macem ada LRA, Neraca, LO, LPE, CALK, kalo yang membuat ini ada adminya trus ditujukan buat BKD, BKDnya nanti merekonsiliasi dulu trus nanti baru dikonsolidasi."

Dalam penyusunan laporan pertanggungjawaban tersebut didasarkan pada berbagai Peraturan Pemerintah dan Undangundang yang berkaitan dengan standar dan kebijakan akuntansi yang diberlakukan, hal ini sesuai dengan pernyataan Ibu A dari Dinas Perdagangn yang mengungkapkan:

"Kita dasarnya itu dari PP 71 tahun 2010 tentang standar akuntans pemerintah, Peraturan Walikota Salatiga No 18 tahun 2016 tentang pedoman pelaksanaan dan pertanggungjawaban anggaran pendapatan dan belanja daerah, UU No 17 tahun 2003 
tentang keuangan negara sama ada PP 58 mas itu tentang pengelolaan keuangan negara."

Hal senada disampaikan oleh Ibu B dari Dinas Pendidikan:

"Untuk dasar dalam penyusunannya kita sesuai PP 71 tahun 2010 tentang standar akuntansi pemerintah, Kebijakan akuntansi sama UU No 17 tahun 2003 tentang ke uangan negara."

Ibu $\mathrm{C}$ dari Dinas Lingkungan Hidup juga mengungkapkan:

"Gini mas kalo dasarnya itu ada beberapa peraturan yang dijadikan dasar, itu ada PP No 58 tahun 2005 tentang pengelolaan keuangan negara, UU No 17 tahun 2003 tentang keuangan negara, PP 71 tahun 2010 tentang standar akuntansi pemerintah, sama ada Pemendagri No 64 tahun 2003 tentang penerapan standar akuntansi berbasis akrual pada Pemda."

Pernyataan yang sama juga diungkapkan oleh Ibu D dari Dinas Perumahan dan Kawasan Pemukiman :

"Dasar penyusunan laporan pertanggungjawabannya itu ada PP 71 tahun 2010 tentang standar akuntansi pemerintah, Peraturan Walikota Salatiga No 69 tahun 2016 atas perubahan ketiga atas Peraturan Walikota Salatiga No 37 tahun 2013 tentang kebijakan akuntansi pemerintah kota Salatiga, Pemendagri No 64 tahun 2013 tentang penerapan standar akuntansi berbasis akrual pada Pemda, UU No 17 tahun 2003 tentang keuangan negara, PP No 58 tentang pengelolaan keuangan negara.",

Bapak E dari Dinas Pekerjaan Umum dan Penataan Ruang juga menyebutkan:
"Jadi dasar dalam penyusunan laporannya itu ada PP 71 tahun 2010 tentang standar akuntansi pemerintah, UU No 17 tahun 2003 tentang keuangan negara, sama ini mas PP No 58 tentang pengelolaan keuangan negara."

BKD bertugas sebagai pihak yang melakukan monitoring proses pembuatan laporan pertanggungjawaban dinas dengan didampingi oleh inspektorat. Dinas membuat laporan pertanggungjawaban dalam dua periode yaitu periode semesteran dan periode tahunan namun beberapa dinas juga membuat laporan setiap bulan. Sebagaimana hal ini diungkapkan oleh Ibu A dari Dinas Perdagangan:

"Untuk prosedur pembuatan laporan keuangannya itu banyak mas kalo penjelasan simplenya ya awalnya itu kita input dulu pendapatan dan belanjanya nanti kita ada sistem namanya sistem informasi pengelolaan keuangan daerah yang bakal mempros es setiap terjadinya transaksi trus kita buat jurnal penyesuaian kalo ada koreksi pencatatan trus nanti sistemnya tadi menghasilkan output laporan keuangan itu, nanti yang mengawasi kegiatan pembuatannya itu ada BKD sama inspektorat. Kita biasanya buat laporan itu setiap bulan sekali buat di validasi sama rekonsiliasi, kemudian juga buat laporan keuangan setiap semester pas bulan juni sama desember."

Ibu B dari Dinas Pendidikan juga mengungkapkan:

"Kita punya RKA sama DPA mas, RKA itu rencana kerja anggaran dan DPA itu merupakan RKA yang telah disahkan menjadi 
dokumen, atas dokumen itulah kita melaksanakan kegiatan seperti pengajuan pencairan dan kegiatan-kegiatan lain yang terkait sampe akhirnya melakukan penatausahaan oleh pejabat penatusahaan keuangan, dimana pejabat tersebut setelah ada pencairan harus membuat SPP, SPM beserta lampiranya. Setelah pencairan dana tersebut selesai kemudian membuat LRA, LO, Neraca, LPE sama CALK. Nantinya yang mengawasi itu BKD sama inspektorat. Laporan pertanggungjawabanya itu dibuat setiap satu bulan sekali mas sama semesteran."

Pernyataan yang sama juga dinyatakan oleh Ibu C dari Dinas Lingkungan Hidup, beliau mengungkapkan:

"Kitakan ada anggaran, dari anggaran tersebut lalu kita realisasikan dalam belanja, selanjutnya dinas akan membuat laporan pertanggungjawaban berupa laporan keuangan berdasarkan dari realisasi tadi, pertama itu buat LRA dulu mas urutanya trus neraca, LO, LPE baru CALK. Kalo yang mengawasi itu BKD, jadi setelah jadi nanti laporan keuangannya kita serahkan ke bagian akuntansi $B K D$ trus BKD didampingi inspektorat nanti ngecek apakah Laporan keuangannya sudah sesuai standar belum. Kalo periode pembuatannya itu dalam satu tahun biasanya dinas dua kali buat yaitu pas semesteran sama akhir tahun."

Hal senada diungkapkan oleh Ibu D dari Dinas Perumahan dan Kawasan Pemukiman: "Jadi kalo prosedurnya itu pertama kita kumpulin dulu input dari semua pendapatan sama belanja, terus nanti ada sistem pengelolaan keuangan yang memproses kalo ada transaksi, terus kalo ada koreksi pencatatan nanti kita buat jurnal penyesuainya kalo udah bener nanti sistemnya akan menghasilkan output berupa laporan keuangan, kalo udah jadi outputnya nanti kita serahkan ke bagian akuntansinya BKD nanti mereka yg ngecek udah bener sesuai standar belum. Kita buat laporan keuangannya itu ada laporan bulanan, semesteran sama tahunan mas."

Hal ini semakin diperkuat oleh pernyataan yang di ungkapkan Bapak E dari Dinas Pekerjaan Umum dan Penataan Ruang:

"Jadi dari anggaran nanti kita realisasikan dulu kalo udah direalisasikan nanti oleh dinas baru dibuat laporan keuangan yang LRA, Neraca, LO, LPE sama CALK tadi, itu kita buatnya juga gabisa sembarangan mas soalnya nanti di cek sama BKD. Kalo periode pelaporannya kita biasanya bulan juni sama akhir tahun jadi bulan desember."

Sesuai dengan Peraturan Pemerintah Nomor 71 Tahun 2010 tentang standar akuntansi pemerintah, akuntabilitas merupakan bentuk pertanggungjawaban atas pengelolaan kebijakan serta sumber daya yang telah dipercayakan kepada entitas pelaporan dalam mencapai tujuan yang sudah ditetapkan secar a periodik. Peraturan tersebutlah yang men dasari dinas wajib untuk accountable dalam melaksanakan kegiatan operasionalnya.

Dalam pelaksanaan pertanggungjawaban keuangannya dinas didasarkan pada perundangundangan dan peraturan pemerintah sesuai dengan yang disebutkan oleh narasumber. Hal ini dimaksudkan agar dalam pelaksanaan 
akuntabilitasnya dinas tidak menyimpang dari aturan dan norma yang ada. Setelah laporan pertanggungjawaban keuangan selesai pun pihak dinas diwajibkan untuk menyerahkanya ke BKD guna dilakukan rekonsiliasi dan pengecekan lebih lanjut sebelum nantinya akan disatukan dengan laporan keuangan dari dinasdinas lain. Kemudian laporan tersebut akan diserahkan kepada pihak yang mempunyai wewenang yang lebih tinggi.

Kewajiban untuk melaksanakan akuntabilitas ini bertujuan agar masyarakat dapat mengawasi dan mengecek kinerja dan kegiatan operasional pemerintah daerah serta sebagai bentuk pertanggungjawaban keuangan masing-masing dinas. Hal ini sesuai dengan pendapat yang dikemukakan oleh Mardiasmo (2002) berkaitan dengan akuntabilitas horisontal sebagai bentuk pertanggungjawaban kepada masyarakat baik secara langsung maupun melalui lembaga perwakilan. Pelaksa naan akuntabilitas LKPD Kota Salatiga sudah sesuai dengan peraturan pemerintah yang berlaku, ini menunjukkan bahwa Kota Salatiga sudah accountable dalam pelaksanaan pengelolaan kebijakan, pengelolaan anggaran serta kegiatan operasional yang ada, hal ini sesuai dengan ciriciri yang sudah di kemukakan oleh Sopanah (2005). Pemerintah daerah memberik an kesempatan bagi masyarakat untuk ikut serta dalam acara-acara resmi yang diselenggarakan oleh pemerintah daerah serta masyarakat dapat memberikan saran maupun kritik melalui website dan media sosial resmi pemerintah Kota Salatiga.

\section{Pelaksanaan Transparansi Laporan Keuangan SKPD}

Laporan keuangan yang dibuat oleh dinas tidak langsung dipuublikasikan kepada masyarakat umum. Setelah setiap dinas membuat laporan keuangan, masing-masing laporan tersebut akan dijadikan menjadi satu dengan dinas-dinas lain dan akan dikelola oleh bagian akuntansi Badan Keuangan Daerah (BKD) untuk dijadikan laporan keuangan

gabungan. BKD kemudian akan menggabungkan dan mengecek laporan keuangan masing-masing dinas. Apabila sudah dilakukan pengecekan oleh BKD laporan tersebut akan diaudit terlebih dahulu oleh BPK, setelah laporan keuangan tersebut diaudit dan sesuai standar yang berlaku laporan keuangan tersebut baru akan dipublikasikan ke masyarakat umum. Hal ini didasarkan pernyataan yang diungkapkan oleh Ibu A dari Dinas Perdagangan:

"Dinas sendiri belum melakukan penguploadan laporan keuangan mas, tetapi kalo dari pemerintah kota seharusnya sudah, karena nanti laporan keuangan dari masing-masing dinas akan digabung jadi satu dengan dinas lainnya dan kemudian akan dikelola menjadi satu kesatuan laporan keuan gan oleh BKD. Nanti kalo udah digabung lapoorannya diaudit dulu sama BPK trus dicek baru diupload di www.salatiga.go.id."

Senada dengan Ibu A dari Dinas Perdagangan, Ibu B dari Dinas Pendidikan juga mengungkapkan:

"Disini dinas punya hak nya untuk mengelola dana tetapi dalam pengelolaan tersebut juga 
akuntabel dan transparan, tapi untuk melaporkannya kepublik itu nanti entitas pelapor (BKD) yang melakukan. Transparansi pada dinas untuk pemeriksaan sebelum laporan tersebut diserahkan ke BKD, setelah laporan sampe ke BKD trus diserahin ke BPK untuk diaudit nanti baru diupload di web pemkot di www.salatiga.go.id.”

Pernyataan yang sama dinyatakan oleh Ibu C dari Dinas Lingkungan Hidup, beliau mengungkapkan,

"Kalau penguploadannya itu laporan dari masing-masing dinas dikumpulkan dulu ditingkat kota untuk dicek BKD, kemudian setelah lolos pengecekan dan diaudit oleh BPK baru BKD akan mengupload lapooran keuangan tersebut ke webnya pemkot itu alamat webnya www.salatiga.go.id."

Hal ini juga sesuai dengan ungkapan Ibu D dari Dinas Perumahan dan Kawasan Pemukiman,

"Jadi dinas nanti tidak langsung mengupload laporan keuangannya mas, nanti kita serahkan dulu laporan keuangannnya ke BKD trus nanti di BKD digabung laporaan keuangannya dari semua dinas, kalo sudah baru nanti diupload ke webnya pemkot di www.salatiga.go.id,tapi sebelum diupload harus diaudit dulu sama BPK mas."

Pernyataan tersebut diperkuat oleh ungkapkan Bapak E dari Dinas Pekerjaan Umum dan Penataan Ruang yang mengungkapkan,

"Kalau yang melakukan transparansi itu nanti pemkot melalui BKD mas, jadi nanti kita serahin dulu laporan keuangannya trus digabungin jadi satu sama dinas-dinas lain, kalo sudah dicek dan diaudit BPK baru diupload, alamat webnya kalo mau lihat laporan keuangan yang sudah diupload itu di www.salatiga.go.id."

Berdasarkan hasil dari wawancara para Pegawai Negeri Sipil yang menjadi narasumber, transparansi itu sangat penting karena dengan adanya transparansi laporan keuangan publik menjadi tahu bagaimana kinerja dan kegiatan operasional yang dilakukan oleh pemerintah daerah. Transparansi berperan penting untuk menumbuhkan kepercayaan masyarakat tentang kinerja pemerintah dan menghilangkan kesan bahwa pemerintah seakan-akan menutupi kegiatan dalam pengelolaan dananya. Hal tersebut sesuai dengan hasil wawancara kepada Ibu A dari Dinas Perdagangan, beliau mengungkapkan:

"Transparansi jelas sangat penting mas soalnya keterbukaan ini kan juga ditujukan buat masyarakat sama pihak-pihak lain yang berkepentingan untuk pengambilan keputusan, supaya laporan keuangan itu bisa diketahui publik, untuk menjaga juga agar tidak ada kesan ditutup-tutupi dalam pelaksanaan kegiatan pemerintahan."

Senada dengan Ibu A dari Dinas Perdagangan, Ibu B dari Dinas Pendidikan juga mengungkapkan:

"Masyarakat pun berhak untuk memantau penggunaan dana, laporan tersebut juga ditujukan untuk stakeholder dalam rangka pengambilan keputusan. Transparansi laporan keuangan ini juga dilakukan sebagai kontrol atas penggunaan dana rakyat. Sehingga disini 
transparansi sangat penting untuk dilakukan."

Pernyataan yangsama dinyatakan oleh

Ibu C dari Dinas Lingkungan Hidup, beliau mengungkapkan:

"Transparansi penting untuk menunjukkan laporan keuangan tersebut akuntabel, agar pihak luar dan masyarakat yang ingin mengetahui bagaimana laporan keuangan dinas itu dapat melihat dan menilai baagaimana laporan keuangan tersebut, laporan keuangan biasanya diupload maksimal tiga bulan setelah tahun berakhir."

Pernyataan tersebut diperkuat oleh ungkapan dari Ibu D dari Dinas Perumahan dan Kawasan Pemukiman:

"Laporan keuangan dipublikasikan untuk masyarakat dan pihak-pihak yang membutuhkan laporan keuangan untuk

pengambilan keputusan. Harus ada keterbukaan mas soalnya masyarakat juga berhak tahu secara terbuka dan menyeluruh tentang pengelolaan keuangan yang dilakukan oleh pemerintah kota."

Bapak E dari Dinas Pekerjaan Umum dan Penataan Ruang juga memperkuat pernyataan Ibu D dengan menyebutkan:

"Tentu keterbukaan laporan keuangan itu sangat itu sangat penting mas, karena masyarakat juga berhak tahu bagaimana pemerintah mengelola dananya, trus juga laporan keuangan itu kan juga ditujukan buat pihak pihak yang berkepentingan untuk pengambilan keputusan."

Transparansi berarti memberikan informasi keuangan yang jujur dan terbuka kepada masyarakat luas. Hal ini sesuai dengan
Peraturan Pemerintah Nomor 71 Tahun 2010 tentang standar akuntansi pemerintah. Peraturan tersebut didasarkan pada pertimbangan bahwa masyarakat umum berhak untuk mengetahui secara terbuka dan menyeluruh mengenai

pertanggungjawaban pemerintah dalam mengelola sumber daya dan kebijakan yang telah dipercayakan kepadanya agar sesuai dengan norma dan peraturan yang ada.

Setiap dinas tidak langsung melakukan transparansi laporan keuangan kepada masyarakat umum karena laporan keuangan yang sudah dibuat tersebut nantinya akan dikumpulkan terlebih dahulu untuk diperiksa oleh BKD dan kemudian diaudit oleh BPK. Setelah diaudit BPK pemerintah Kota Salatiga baru akan melaksanakan transparansi LKPD. Ini menunjukkan bahwa pemerintah Kota Salatiga sudah transparan dalam pengelolaan

keuangan maupun kegiatannya karena pelaksanaan transparansi tersebut sudah sesuai dengan peraturan pemerintah yang berlaku. Salah satu tujuan dari transparansi adalah untuk menunjukkan keterbukaan mengenai pertanggungjawaban keuangan dan kinerja pemerintah. Seperti yang diungkapkan oleh Kusuma (2002) transparansi sangat penting guna menumbuhkan kepercayaan dan keyakinan dari masyarakat bahwa pemerintah daerah merupakan instansi pelayanan publik yang profesional dan bebas dari tindakan kecurangan. Dengan adanya transparansi masyarakat dapat mengukur dan mengawasi kinerja serta pertanggungjawaban keuangan pemerintah daerah sehingga dapat mencegah kecurangan yang dapat terjadi. Hal ini sesuai 
dengan pendapat Andrianto (2007) yang menyatakan bahwa transparansi dapat mencegah korupsi serta meningkatkan akuntabilitas pada pemerintah sehingga masyarakat lebih mampu untuk mengukur kinerja pemerintah. Erlanda dan Khairudin (2016) juga mengungkapkan hal yang sama bahwa transparansi adalah salah satu unsur guna menyelenggarakan negara yang bersih dan bebas dari KKN.

\section{Potensi Whistleblowing atas Penyalahgunaan Pengelolaan Dana}

Whisthleblowing sangat penting guna membantu pemerintah dalam mengungkap tindakan ilegal yang terjadi di instansi pemerintahan. Dalam hasil wawancara tentang potensi para pegawai negeri sipil untuk menjadi whistleblower dengan kaitanya bahwa masyarakat dapat melakukan pengawasan pengelolaan dana dan kinerja pemerintah melalui akuntabilitas dan transparansi yang dilakukan masing-masing dinas, para Pegawai Negeri Sipil yang menjadi narasumber berpendapat bahwa mereka hanya mempunyai wewenang untuk menyusun akuntabilitas laporan keuangan dan menyerahkannya ke bagian akuntansi BKD untuk dilakukan pengecekan sebelum diupload, mereka merasa tidak mempunyai wewenang untuk mengungkapkan kecurangan yang terjadi dan memilih untuk menunggu pihak yang berwenang dalam hal ini auditor untuk mengungkap kecurangan apabila terjadi. Sebagaimana hal ini dinyatakan oleh Ibu A dari Dinas Perdagangan:
"Ya dinas memang sudah melakukan akuntabilitas dan transparansi mas jadi masyarakat memang bisa mengawasi,tapi kalo misal ada penyalahgunaan dana itu kita nanti ada inspektorat dan auditor yang menindaklanjuti, jadi saya hanya melakukan tugas dan kewajiban saya untuk memberikan laporan pertanggungjawaban dan menyerahkannya ke BKD, untuk mengungkapkanya itu bukan ranah saya mas."

Senada dengan Ibu A dari Dinas Perdagangan, Ibu B dari dinas Pendidikan juga mengungkapkan:

"Saya disini hanya melakukan tugas pokok fungsi saya, dalam hal ini saya hanya berkewajiban dan mempunyai wewenang untuk melakukan verifikasi dan penatausahaan untuk laporan keuangan, sehingga untuk mengungkapkan penyelewengan dana yang ada itu bukan ranah saya, itu ranahnya auditor internal nanti."

Hal yang sama diungkapkan oleh Ibu C

dari Dinas Lingkungan hidup yang mengungkapkan:

"Ya saya kan tugasnya cuma dipenatausahaan buat laporan keuangannya mas, masyarakat memang bisa mengawasi melalui akuntabilitas dan transparansi yang ada tapi kalo misal ada kecurangan penyalahgunaan dana dan saya tahu ya itu bukan wewenang saya untuk mengungkapkan."

Sejalan dengan pernyataan Ibu A, B dan C, Ibu D dari Dinas Perumahan dan Kawasan Pemukiman juga mengungkapkan:

"Wah kalo itu bukan wewenang saya mas bukan ranah saya, saya tugasnya cuma 
dipenatausahaan, kalo urusan mengungkapkan penyelewengan atau kecurangan penyalahgunaan dana itu nanti tugasnya inspektorat sama auditor internal, jadi ya saya cuma menjalankan apa yang menjadi tugas pokok saya, yang penting kita sudah menjalankan kewajiban untuk melaksanakan akuntabilitas dan transparansinya biar masyarakat tau."

Pernyataan tersebut diperkuat oleh ungkapan dari Bapak E dari Dinas Pekerjaan Umum dan Penataan Ruang, beliau mengungkapkan:

"Itu biar nanti jadi urusannya auditor internal mas, kewajiban dan tugas saya kan cuma dipenatausahaan laporan keuangannya, kalo sampe melaporkan kecurangan penyalahgunaan dana itu sudah bukan ranah saya."

Whistleblower dapat membantu pemerintah untuk mengungkapkan tindakan ilegal yang dapat merugikan negara dan masyarakat. Seseorang yang ingin menjadi whistleblower harus mempunyai bukti dan informasi yang jelas agar dapat ditindaklanjuti oleh pihak yang berwenang sesuai dengan pernyataan Keraf (2008). Dalam lingkup instansi pemerintah para Pegawai Negeri Sipil merupakan individu yang paling berpotensi untuk menjadi whistleblower. Hal ini sesuai dengan penelitian Mesmer-Magnus dan Viswesvaran (2005) yang menyatakan bahwa dalam instansi pemerintah pengguna potensial diterapkannya sistem whistleblowing adalah para pegawai negeri sipil, hal ini dikarenakan mereka terlibat secara langsung dan memiliki informasi rinci tentang proses berjalannya kegiatan operasional dan bagaimana instansi tersebut bekerja.

Pegawai Negeri Sipil yang menjadi narasumber dalam penelitian ini memilih untuk menunggu pihak yang berwajib dalam mengungkapkan kecurangan penyalahgunaan dana yang ada karena mereka merasa tidak mempunyai hak dan wewenang untuk mengungkapkan kecurangan tersebut. Hal tersebut bisa didasari berbagai pertimbangan yang ada mengingat bahwa whistleblowing merupakan tindakan yang beresiko karena tindakan ini nantinya berhubungan dengan nama baik suatu instansi maupun individu yang berkaitan. Oleh karena itu tidak semua orang berani untuk mengungkapkan kecurangan yang ada kepada pihak lain. Hal sesuai juga diungkapkan oleh Park dan Blenkinsopp (2009) bahwa resiko pembalasan yang diterima oleh pelaku whistleblower secara tidak langsung dapat mempengaruhi niat individu untuk melaporkan kecurangan.

Pemerintah sebenarnya sudah menjamin keamanan para pelaku whistleblower melalui UU Nomor 13 Tahun 2006 tentang perlindungan saksi dan korban, undang-undang ini berisi tentang perlindungan atas keluarga, keamanan pribadi dan harta bendanya serta bebas dari ancaman yang terkait dengan kesaksian yang akan, sedang atau telah diberikan, sehingga Pegawai Negeri Sipil yang ada seharusnya tidak perlu merasa takut lagi menjadi whistleblower. 


\section{KESIMPULAN \&}

\section{SARAN Kesimpulan}

Hasil penelitian ini menunjukkan bahwa pemerintah Kota Salatiga sudah accountable dan transparan dalam pelaporan keuangan pemerintah daerah serta tidak ada potensi whistleblowing atas penyalahgunaan dana. Pegawai negeri sipil merasa bahwa transparansi dan akuntabilitas LKPD merupakan komponen yang sangat penting karena hal itu merupakan bentuk keterbukaan serta pertanggungjawaban kinerja dan pengelolaan keuangan oleh pemerintah.

Dengan adanya akuntabilitas dan transparansi LKPD masyarakat dapat ikut mengawasi kinerja pemerintah daerah agar bekerja sesuai dengan amanah yang diberikan dan tidak melakukan tindakan ilegal untuk kepentingan individu maupun kelompok yang dapat merugikan masyarakat dan negara. Namun pada kenyataannya narasumber merasa bahwa untuk mengungkapkan tindakan penyalahgunaan dana yang bisa saja terjadi di instansi tempat mereka bekerja itu bukanlah hak dan wewenang mereka.

\section{Implikasi Terapan}

Hasil penelitian ini dapat digunakan sebagai bahan evaluasi bagi instansi pemerintah untuk membuat mekanisme whistleblowing yang baik misalnya adanya jaminan keselamatan berdasarkan hukum yang ada agar Pegawai Negeri Sipil yang bekerja pada SKPD lebih berani untuk mengungkapkan kecurangan serta memberikan reward khusus bagi para whistleblower.

\section{Saran}

Penelitian ini terbatas pada jumlah dinas yang menjadi objek wawancara dan topik penelitian yang sensitif dan beresiko sehingga dikhawatirkan hasil wawancara dari narasumber tidak mencerminkan keadaan yang sesungguhnya karena adanya kepentingankepentingan untuk melindungi individu atau instansi yang bersangkutan. Bagi penelitian selanjutnya, diharapkan dapat mengembangkan penelitian ini pada aspek yang lain misalnya seperti independensi, responsibilitas, dan lain sebagainya.

\section{DAFTAR PUSTAKA}

Andrianto, N. 2007. Good e-government: transparansi dan akuntabilitas publik melalui e-government. Malang: Bayumedia publising, anggota IKAPI Jatim.

Erlanda, R dan Khairudin. 2016. Pengaruh transparansi dan akuntabilitas Laporan Keuangan Pemerintah Daerah (LKPD) terhadap tingkat korupsi pemerintah daerah (Studi pada Pemerintah Kota SeSumatera). Jurnal akuntansi dan keuangan 7(2): 137-154.

Heriningsih, S dan Marita. 2013. Pengaruh opini audit dan kinerja keuangan daerah terhadap tingkat korupsi pemerintah daerah (Studi empiris pada Pemerintah Kabupaten dan Kota di Pulau Jawa). Buletin ekonomi 11 (1).

Keraf, S. 2008. Etika bisnis. Yogyakarta: Kanisius.

Komisi Pemberantasan Korupsi. 2014. Integritas sektor publik tahun 2013: fakta korupsi dalam layanan publik. Jakarta: KPK. 
Kusuma, M. 2012. Pengaruh akuntabilitas terhadap transparansi penyusunan laporan keuangan pemerintah daerah (Studi empiris terhadap persepsi mahasiswa diploma akuntansi di Kediri). Cahaya aktiva 2(2): 45-57.

Mardiasmo. 2002. Akuntansi sektor publik. Yogyakarta: ANDI Yogyakarta.

Mardiasmo. 2002. Otonomi daerah sebagai upaya memperkokoh basis perekonomian daerah. Seminar pendalaman Ekonomi Rakyat.

Mesmer-Magnus, J. R dan Viswesvaran, C. 2005. Whistleblowing in organizations: An examination of correlates of whistleblowing intentions, actions, and retaliation. Journal of Business Ethics 62 (3): 277-297.

Park, H dan Blenkinsopp, J. 2009. Whistleblowing as planned behavior $-\mathbf{a}$ survey of south korean police officers. Jurnal of business ethics 85: 545-556.

Pemerintah Kota Salatiga. 2017. available at: www.salatiga.go.id. Diakses tanggal 1 Juni 2017.

Peraturan Menteri Dalam Negeri Nomor 13 Tahun 2006 tentang pedoman pengelolaan keuangan daerah.

Peraturan Pemerintah Republik Indonesia Nomor 71 Tahun 2010 tentang standar akuntansi pemerintah.

Sopanah. 2005. Pengaruh akuntabilitas publik, partisipasi masyarakat, transparansi kebijakan publik terhadap hubungan antara pengetahuan anggaran daerah dengan pengawasan keuangan daerah. Jurnal logos 3(1).

Transparency International. 2017.“Corruption perception index 2016", available at: www. transparency.org/cpi2016/. Diakses tanggal 22 Juni 2017.

Undang - Undang Nomor 13 Tahun 2006 tentang Perlindungan Saksi dan Korban.
Undang-Undang Nomor 17 Tahun 2003 Tentang Keuangan Negara. 